\title{
Facilitative effects of introduced Pacific oysters on native macroalgae are limited by a secondary invader, the seaweed Sargassum muticum
}

\author{
Anne C. Lang a, Christian Buschbaum ${ }^{\mathrm{b}, *}$ \\ a Institute of Ecology and Environmental Chemistry, Leuphana University Lüneburg, Scharnhorststr. 1, 21335 Lüneburg, Germany \\ ${ }^{\mathrm{b}}$ Alfred Wegener Institute for Polar and Marine Research, Wadden Sea Station Sylt, Hafenstr. 43, 25992 List, Germany
}

\section{A R T I C L E I N F O}

Article history:

Received 17 June 2009

Received in revised form 12 November 2009

Accepted 13 November 2009

Available online 22 November 2008

\section{Keywords:}

Algal Canopy

Epibenthos

Infauna

Introduced Species

Understorey Algae

\begin{abstract}
A B S T R A C T
Introduced habitat-providing organisms such as epibenthic bivalves may facilitate the invasion and expansion of further non-native species which may modify the effects of the primary invader on the native system. In the sedimentary intertidal Wadden Sea (south-eastern North Sea) introduced Pacific oysters (Crassostrea gigas) have overgrown native blue mussel beds (Mytilus edulis). These oyster beds are now providing the major attachment substratum for macroalgae. Recently, oysters have expanded their distribution into the shallow subtidal zone of the Wadden Sea, and there support a rich associated species community including the Japanese seaweed Sargassum muticum, which has been presumably introduced together with the oysters. With a block designed field experiment, we explored the effects of $S$. muticum on the associated community of soft-bottom C. gigas beds in the shallow subtidal. Replicated oyster plots of $1 \mathrm{~m}^{2}$ were arranged with a density of $0,7,15$ or $45 \mathrm{~S}$. muticum $\mathrm{m}^{-2}$, respectively. We found no effects of different $S$. muticum densities on associated epi- and endobenthic community compositions associated to the oyster plots. However, the overall coverage of sessile organisms settling on the oyster shells was significantly reduced at high $S$. muticum densities. The occurrence of abundant native macro-algal species such as Polysiphonia nigrescens, Antithamnion plumula and Elachista fucicola decreased with increasing S. muticum densities. Sessile invertebrates, by contrast, were only marginally affected and we found no effects of S. muticum canopy on diversity and abundance of endofauna organisms. We conclude that increasing densities of $S$. muticum on $C$. gigas beds in the shallow subtidal zone of the Wadden Sea limit the occurrence of native macroalgae which otherwise would benefit from the additional hard substratum provided by the oysters. Thus, a secondary invader may abolish the effects of the primary invader for native species by occupying the new formed niche.
\end{abstract}

(C) 2009 Elsevier B.V. All rights reserved.

\section{Introduction}

Introduced marine species can cause major effects on the recipient community by changing physical factors, community structure and ecosystem properties (e.g. Callaway and Josselyn, 1992; Bruno, 2000; Grosholz et al., 2000; Crooks and Khim, 2002; Ruesink et al., 2006). Jones et al. (1994) established the term ecosystem engineer for "species that modulate the availability of resources, by causing major changes in biotic and abiotic materials". Coastal environments may be strongly affected if invasive species are ecosystem engineers that provide new habitats in recipient systems (Crooks and Khim, 2002; Cuddington and Hastings, 2004; Buschbaum et al., 2006; Wallentinus and Nyberg, 2007; Sousa et al., 2009). The additional structures may facilitate the invasion of further non-native species. This positive interaction of non-indigenous species is termed invasional melt-

\footnotetext{
* Corresponding author. Tel.: +49 4651956 4228; fax: +49 46519564200.

E-mail addresses: anne.lang@uni-lueneburg.de (A.C. Lang), Christian.Buschbaum@awi.de (C. Buschbaum).
}

down' and may cause accelerated effects on recipient ecosystems (Simberloff and Von Holle, 1999).

In addition to molluscs, macroalgae are regarded as important habitat-providing invasive marine engineers (Reise et al., 2002; Gutiérrez et al., 2003; Schaffelke et al., 2006; Borthagaray and Carranza, 2007; Schaffelke and Hewitt, 2007; Wallentinus and Nyberg, 2007; Buschbaum et al., 2009; Sousa et al., 2009). Non-native algae may alter the recipient community by increasing structural complexity that may enhance species richness and diversity (Crooks and Khim, 2002; Buschbaum et al., 2006). They may also affect algal and faunal understorey assemblages by modifying physical factors such as water flow (Velimirov and Griffiths, 1979; Eckman et al., 1989; Duggins et al., 1990; Russell, 2007), sedimentation rate (Eckman et al., 1989; Connell, 2005) and light conditions (Kennelly, 1989; Connell, 2003; Toohey et al., 2004; Connell, 2005). In addition, sweeping algal fronds can affect other sessile organisms such as barnacles by scouring the substratum (Leonard, 1999; Irving and Connell, 2006).

A very successful invasive alga is the Japanese seaweed Sargassum muticum (Yendo) Fensholt (Phaeophyceae, Fucales) which was first 
described from Japan and has currently an almost worldwide distribution (Critchley et al., 1990b). In the European Wadden Sea, it was first detected in the western part near the island of Texel in 1981 and reached the northern Wadden Sea in 1994 (Schories and Albrecht, 1996; Wolff, 2005). Reasons for its very efficient spreading are the physiological traits of the germlings (Hales and Fletcher, 1989) and its high reproductive potential (Fletcher, 1980; Norton, 1981). Germlings of S. muticum are tolerant to a wide range of salinities, temperatures and light regimes (Hales and Fletcher, 1989). The alga is self-fertilizing and its fronds are breaking off in late summer serving as floating vehicles for propagules (Fletcher, 1975, 1980; Norton, 1977, 1981). An additional dispersal vector is human mediated transport with the Pacific oyster Crassostrea gigas (Thunberg) (Druehl, 1973; Critchley and Dijkema, 1984). The occurrence of S. muticum in an invaded area depends on the availability of hard substratum and is restricted by physical factors such as strong wave action, high sedimentation rates and limited light conditions (Viejo et al., 1995; Thomsen, 2006).

S. muticum has usually been considered an ecosystem engineer because it may influence a number of physical factors such as light conditions beneath dense seaweed canopies and might also affect water flow, sedimentation rate, water temperature and nutrient composition within algal beds (Critchley et al., 1990a,b; BrittonSimmons, 2004; Strong et al., 2006; Domisch, 2008). These changes in abiotic conditions may cause different effects on recipient algal assemblages (Olabarria et al., 2009; Sánchez and Fernández, 2005). Negative effects of $S$. muticum on diversity and abundance of native algal communities are reported from western Pacific coasts (from British Columbia through Washington State to California) and also from European coasts (Denmark, Scotland and Spain) (Ambrose and Nelson, 1982; de Wreede, 1983; Viejo, 1997; Staehr et al., 2000; Britton-Simmons, 2004; Harries et al., 2007). However, also facilitating effects on species numbers and diversity of less dominant algae of an invaded assemblage were observed. For example, at the north coast of Spain (north-east Atlantic) Sánchez et al. (2005) found that abundance of dominant native species may be reduced but total resident algal species number and diversity increased after establishment of S. muticum. Similar to consequences of S. muticum introduction on native algae the effects on resident benthic invertebrates may also be variable. On the Pacific coast of North America, for instance, invertebrate communities were not affected by $S$. muticum (Britton-Simmons, 2004) while at coasts of the Irish Sea and the English Channel (north-east Atlantic) soft-bottom assemblages were different inside and outside S. muticum canopies (Strong et al., 2006). Consequently, effects of $S$. muticum introduction may be different and strongly depend on the considered variables in the native system (Williams and Smith, 2007).

In the sedimentary environment of the Wadden Sea, Buschbaum et al. (2006) revealed that $S$. muticum increases associated epibiota diversity because $S$. muticum provides a habitat which is much more structured than native macroalgae occurring in the area. However, for the area no studies exist that investigate the impacts of S. muticum on the habitat it is attached to. Shortly after its introduction, S. muticum predominantly used epibenthic mussel beds of Mytilus edulis L. for recruitment which represented the major hard substratum available. However, within the last 5 years a dominance shift from native mussels to Pacific oysters C. gigas occurred and oyster shells are representing today the dominant attachment substratum for S. muticum (Polte and Buschbaum, 2008). The rapid shift from mussel beds to aggregations dominated by oysters caused changes in the associated species assemblage (Diederich et al., 2005; Kochmann et al., 2008; Reise, 2008). In the shallow subtidal zone, this habitat is currently changing again because oyster beds become increasingly overgrown by S. muticum. Therefore, this study focuses on the impacts of $S$. muticum overgrowth on the associated species community of an oyster bed and investigates the scenario that $S$. muticum abundances will further increase in the future. We hypothesized that $S$. muticum coverage affects species abundance and diversity of an oyster bed and that these effects depend on $S$. muticum density. To explore these hypotheses we performed a field experiment with different S. muticum densities on experimental oyster plots. The aim was to answer the following questions: (i) Does a S. muticum canopy affect the endobenthic community of an oyster bed? (ii) Does a S. muticum canopy have an impact on the recruitment of sessile faunal and algal species settling on oyster shells? (iii) Do the effects depend on S. muticum density?

\section{Materials and methods}

\subsection{Study site}

Investigations and experiments were performed in a sheltered bay named "Königshafen" at the island of Sylt $\left(54^{\circ} 55^{\prime} \mathrm{N}, 008^{\circ} 20^{\prime} \mathrm{E}\right)$ in the northern Wadden Sea (German Bight, North Sea) (Fig. 1). The bay is drained and flooded by a tidal creek. The semi-diurnal tides in this area range up to $2 \mathrm{~m}$. Mean water temperatures vary from $15^{\circ} \mathrm{C}$ in summer to $4{ }^{\circ} \mathrm{C}$ in winter. Average salinity is 30 and maximum nearbottom current velocities range between 0.3 and $0.5 \mathrm{~m} \mathrm{~s}^{-1}$ (Austen, 1994a). Detailed descriptions of geology, hydrodynamics and sediment composition in the area can be found in Bayerl and Higelke (1994) and Austen (1994a,b). Further information on biota is given by Reise (1985), Reise et al. (1989, 1994) and Schories et al. (1997).

\subsection{Experimental design}

A field experiment was established to test the influence of S. muticum canopies on oyster bed communities in the shallow subtidal zone (0.3-0.5 m below mean low water tide level) of the Wadden Sea. The experiment was set up on a sand flat in close proximity to an oyster bed where S. muticum naturally occurs (Fig. 1). Each experimental unit (plot) had a size of $1 \mathrm{~m}^{2}$ and consisted of 160 individuals of $C$. gigas collected from the oyster bed nearby (Fig. 2a). The oysters were carefully transplanted together with the associated species assemblage to ensure a natural community at the beginning of the experiment. Previous studies revealed that $S$. muticum density in the study area is about 7-10 individuals $\mathrm{m}^{-2}$ and remains stable from the end of April to October (Buschbaum et al., 2006; Polte and Buschbaum, 2008). Experimental plots with four S. muticum density treatments were established: (i) no S. muticum, (ii) density of 7 individuals $\mathrm{m}^{-2}$, (iii) density of 15 individuals $\mathrm{m}^{-2}$ and (iv) a density of 45 individuals $\mathrm{m}^{-2}$. Densities were kept constant during the experimental period (end of April to October 2007) by adding algal thalli when they were lost. We used density treatments instead of coverage since cover is changing with ongoing seasonal growth of the $S$. muticum thalli. The four density treatments were arranged in a randomized block design with 4 blocks each comprising 5 experimental units. Each block contained every density treatment ensuring full orthogonality of the experiment which enabled us to test for block effects (Fig. 2c). Additionally, each density treatment was replicated in one of the blocks to test for possible interactions between treatment and block factor.

\subsection{Sampling}

\subsubsection{Sessile organisms}

To test for effects of $S$. muticum on the recruitment of sessile species living attached to an oyster bed we chose oysters with a shell length of 150 to $160 \mathrm{~mm}$ from which we carefully removed all epibionts and used them as a recruitment matrix. Experiment beginning was two weeks after establishment of the plot at the end of April 2007. For each plot 20 cleaned oysters were marked and randomly placed in the inner part ( $>20 \mathrm{~cm}$ from edge). After an 


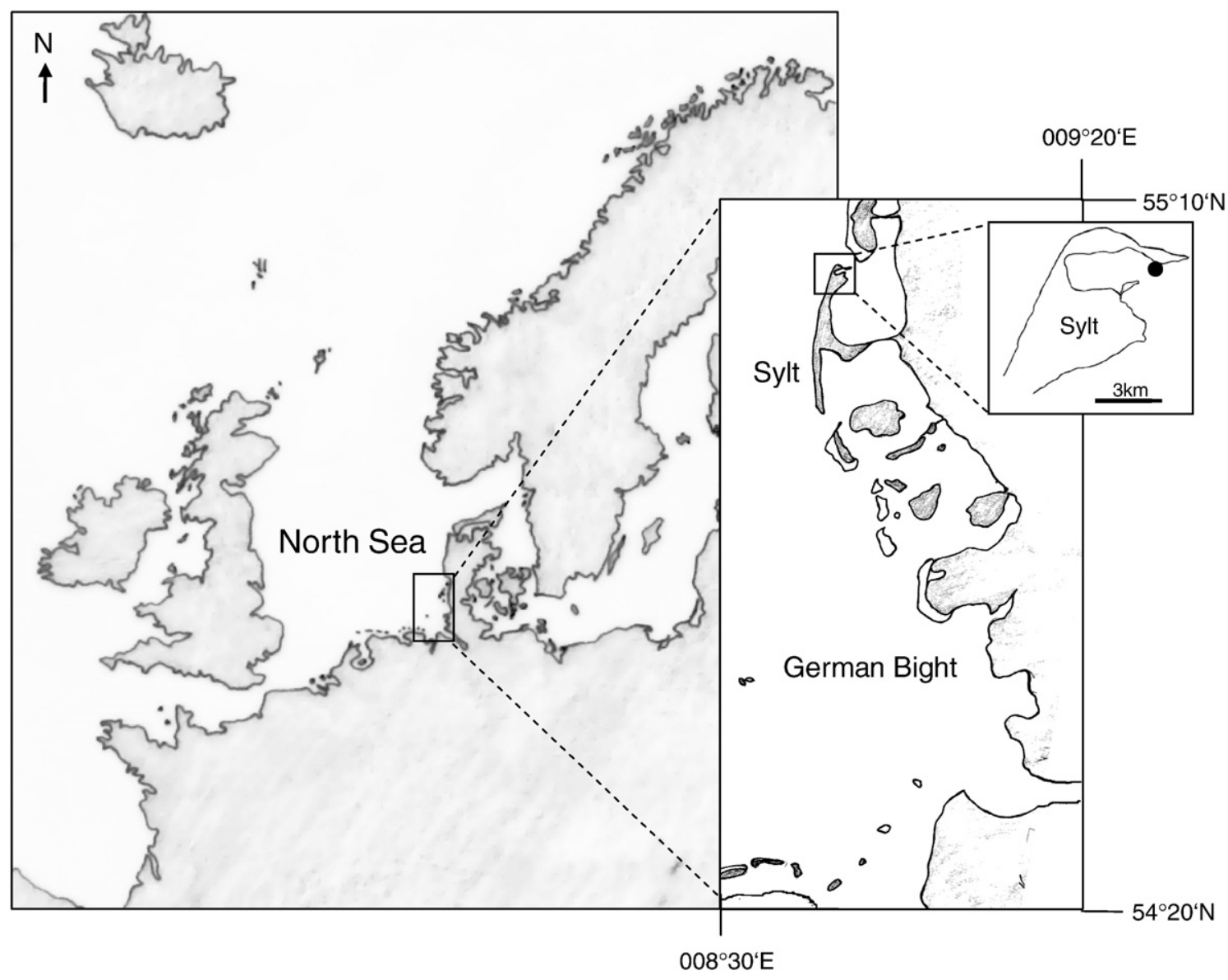

Fig. 1. Study site ( ) at the northern tip of the island of Sylt (German Bight, North Sea).

experimental period of 3 months (July 2007) and 6 months (October 2007), 10 marked oysters per plot were randomly sampled, respectively. Oysters were taken to the laboratory and sediment was carefully removed by rinsing them over a sieve. Afterwards, sessile macroscopic algae and invertebrates were identified to species (or nearest possible taxonomic) level using a stereomicroscope.

For each oyster, percentage cover of all attached species was determined to the nearest $5 \%$. Individual numbers of sessile faunal species (e.g. barnacles) were additionally counted and their abundance oyster ${ }^{-1}$ determined. This was not done for macroalgae due to difficulties in distinguishing single individuals in most species.

\subsubsection{Endobenthic organisms}

The infauna was sampled once in August 2007 during low tide. Samples were taken by using a tube corer of $5 \mathrm{~cm}$ of diameter (sampling depth: $5 \mathrm{~cm}$ ). To compensate for a possible patchy distribution of organisms, six samples were randomly taken from the inner part of each plot ( $>20 \mathrm{~cm}$ from edge, Fig. $2 \mathrm{~b}$ ) and pooled afterwards (total sample volume $98 \mathrm{~cm}^{3}$ ). Samples were washed over a sieve of $250 \mu \mathrm{m}$ mesh size and organisms retained were counted and determined to species (or nearest possible taxonomic) level using a stereomicroscope.

\subsection{Water flow measurement}

The relative near-bottom water velocity within the experimental plots was measured by means of weight loss of gypsum pieces. Gypsum (Bob Stone® DIN1168) was filled into muffin forms embedding plastic sticks for later fixation. The muffins were dried for one week at $50{ }^{\circ} \mathrm{C}$, fixed with the plastic sticks to iron rods using cable ties and then placed in the inner part of the experimental plots from September 28 to September 29, 2007. One gypsum muffin per plot was positioned $10 \mathrm{~cm}$ above the bottom and thus right above the oysters. After $24 \mathrm{~h}$ (spanning two high tides and one low tide) muffins were brought to the laboratory and weighted after being dried again (at $50{ }^{\circ} \mathrm{C}$ for $7 \mathrm{~d}$ ). Weight loss was determined and used as a proxy of flow velocity in the treatments (method similar to Eckman et al., 1989).

\subsection{Sediment characteristics}

To test for effects of S. muticum overgrowth on sedimentation within an oyster reef we determined sedimentation rate within the experimental plots. Bottles with a volume of $500 \mathrm{ml}$, an opening diameter of $3.5 \mathrm{~cm}$ and a height of $21 \mathrm{~cm}$ were used as sediment traps. The ratio of height to width of the used bottles was $6: 1$ and within the range recommended by Gardner (1980) for water velocities higher than $0.15 \mathrm{~m} \mathrm{~s}^{-1}$. Flow velocity at our study area ranges from 0.3 to $0.5 \mathrm{~m} \mathrm{~s}^{-1}$ (Austen, 1994a). For better handling each bottle was put in a PVC tube with a diameter of $10 \mathrm{~cm}$ which was placed randomly in the inner part of each plot. The opening of the tube was on the same height as the top of the oysters preventing oyster faeces from falling into the bottles. Additionally, the tube opening was covered with a net (mesh size of $6 \mathrm{~mm}$ ) to prevent mobile organisms such as crabs from entering into the trap. Sediment was collected for $14 \mathrm{~d}$ from August 23 to September 5, 2007 spanning a neap-spring tidal period using one 


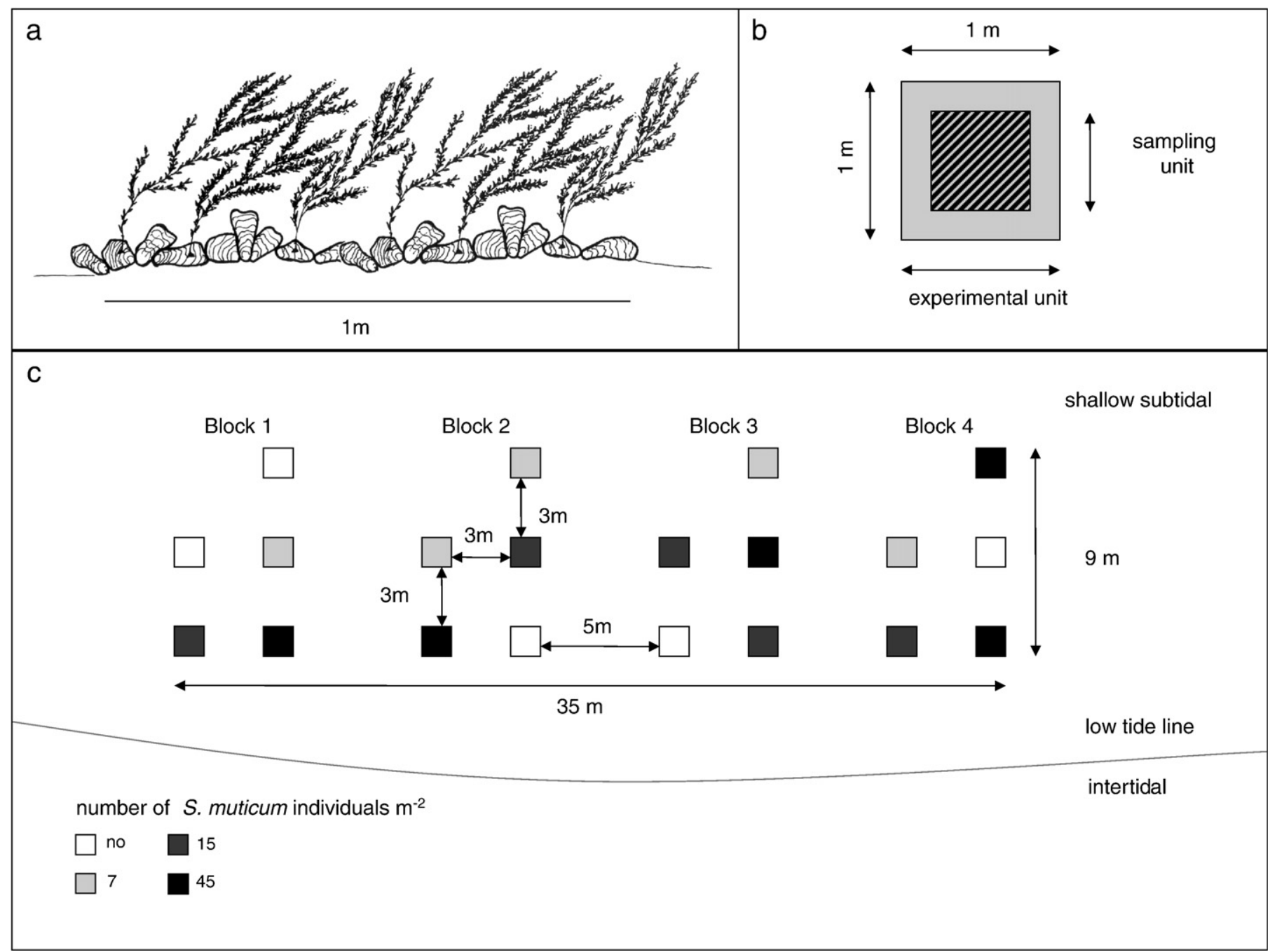

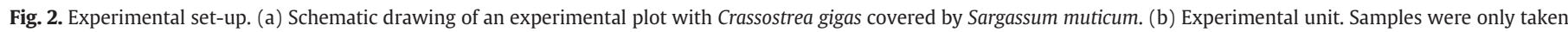
from the inner part to avoid edge effects. (c) Arrangement of the experimental plots in four blocks.

sediment trap per plot. At the end of the experiment, trapped sediment was washed with freshwater to remove salt and dried afterwards. To analyse sediment grain size distribution the dry
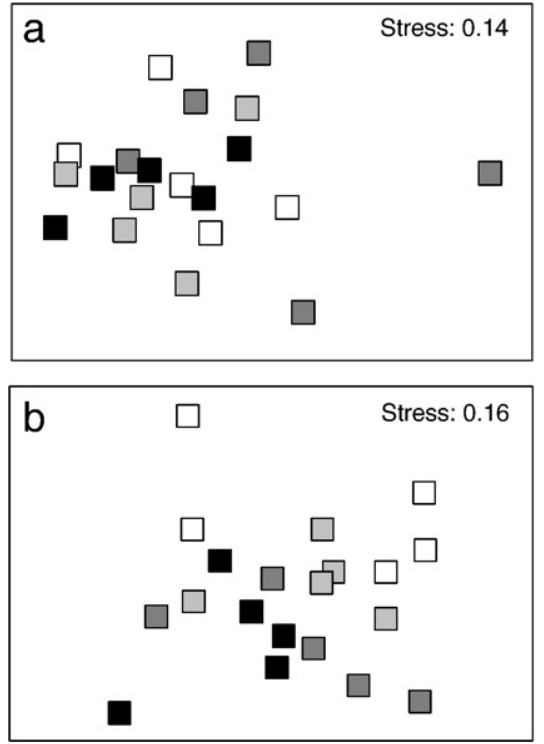

sediments were shaken in a stack of five sieves with decreasing mesh sizes (mesh sizes: 1000, 600, 250,125, and $63 \mu \mathrm{m}$ ) for 6 min and fractions were weighted to the nearest $0.1 \mathrm{~g}$.

number of $S$. muticum individuals $\mathrm{m}^{-2}$
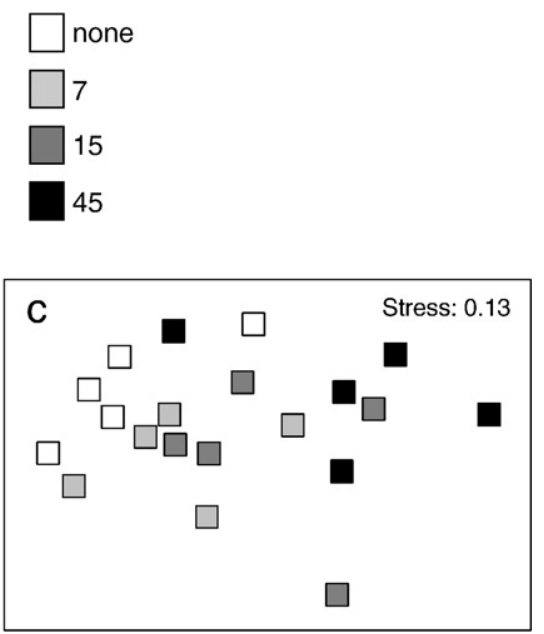

Fig. 3. MDS plots of species assemblages based upon Bray-Curtis similarities. (a) Endobenthic organisms (b) epibenthic organisms - July and (c) epibenthic organisms - October. 


\subsection{Statistical analysis}

Analysis of variance (ANOVA) was used to test for differences in species abundances (epibionts and endofauna) and abiotic factors (flow velocity and sedimentation rate). The randomized block design was used to test for spatial heterogeneity between block sites. S. muticum density was used as a fixed factor and the block as random factor. Interactions between block factor and treatments showed no significance $(p>0.05)$. Only in one case (effects of $S$. muticum occurrence on the abundance of $B$. crenatus in July) a significant effect was found $(p=0.048)$ and we decided to neglect interactions to enhance the power of the analysis (Underwood, 1997). All data were tested for homoscedasticity using Cochran's test. Abundance data needed to be $\log (x+1)$ transformed to fulfill homogeneity of variances. The post-hoc Tukey HSD test was used for comparisons between different $S$. muticum densities.

Community analysis was conducted using multivariate, nonparametric ordination technique (Multidimensional Scaling) based upon the Bray-Curtis similarity comparisons with the Primer TM software (Clarke and Warwick, 2001). For analyses of similarity (ANOSIM) of epibenthic communities we worked with percent coverage oyster ${ }^{-1}$ data while we used abundance data for the analyses of endobenthic communities.

Results are presented as means with standard deviation. Effects were considered to be statistically significant if $p$-value was $<0.05$.

\section{Results}

\subsection{Community responses}

We detected no differences in the community composition between treatments with different $S$. muticum density neither in the endobenthic ( $R$-value of $-0.278 ; p>0.05$ ) nor in the epibenthic assemblage in July $(R$-value of $0.222 ; p>0.05)$ and October $(R$-value of $-0.111 ; p>0.05)$ (Fig. 3).

In total, we recorded 50 species in our experimental plots. In August 2007, we found 17 endobenthic species with a dominance of Annelida and Mollusca (Table 1). Number of endobenthic species in each treatment was 12 and no differences in the occurrence of single

Table 1

List of endobenthic species detected in experimental treatments of different Sargassum muticum densities (ind. $\mathrm{m}^{-2}$ ) in August 2007

\begin{tabular}{|c|c|c|c|c|}
\hline Species & 0 & 7 & 15 & 45 \\
\hline \multicolumn{5}{|l|}{ Nemertea } \\
\hline Nemertini unidentified & $\mathrm{p}$ & $\mathrm{p}$ & & $\mathrm{p}$ \\
\hline Lineus ruber (Müller) & $\mathrm{p}$ & & $\mathrm{p}$ & \\
\hline \multicolumn{5}{|l|}{ Annelida } \\
\hline Aricidea minuta (Southward) & $\mathrm{c}$ & $\mathrm{p}$ & $\mathrm{p}$ & $\mathrm{p}$ \\
\hline Capitella capitata (Fabricius) & c & c & c & c \\
\hline Eulalia viridis (Linné) & & & $\mathrm{p}$ & $\mathrm{p}$ \\
\hline Malacoceros fuliginosus (Claparède) & c & $\mathrm{c}$ & c & c \\
\hline Nereis diversicolor (O. F. Müller) & & $\mathrm{p}$ & $\mathrm{p}$ & \\
\hline Phyllodoce mucosa (Oersted) & $\mathrm{p}$ & & & \\
\hline Scoloplos armiger (O. F. Müller) & $\mathrm{p}$ & $\mathrm{p}$ & $\mathrm{p}$ & $\mathrm{p}$ \\
\hline Tharyx killariensis (Southern) & $\mathrm{a}$ & $\mathrm{a}$ & c & $\mathrm{a}$ \\
\hline Tubificoides benedii (d' Udekem) & $\mathrm{d}$ & d & $\mathrm{d}$ & $d$ \\
\hline Tubificoides pseudogaster (Dahl) & $\mathrm{d}$ & d & $\mathrm{d}$ & $\mathrm{d}$ \\
\hline Tubificoides sp. & $\mathrm{d}$ & d & $\mathrm{c}$ & d \\
\hline \multicolumn{5}{|l|}{ Mollusca } \\
\hline Mya arenaria (Linneus) & & $\mathrm{p}$ & & $\mathrm{p}$ \\
\hline Mysella bidentata (Montagu) & & & $\mathrm{p}$ & \\
\hline Macoma balthica (Linneus) & $\mathrm{p}$ & & & \\
\hline Venerupis sp. & & $\mathrm{p}$ & & $\mathrm{p}$ \\
\hline Total number of endobenthic species 17 & 12 & 12 & 12 & 12 \\
\hline
\end{tabular}

Semi-quantitative data on species abundances are given as mean individual counts per $98 \mathrm{~cm}^{3}$ : p) present $<1$, c) common $1-5$, a) abundant $6-10$, d) dominant $>10$. species between the treatments were detected (two-factorial ANOVA, $p>0.05$ for all species).

The total number of epibenthic species was 33 with 19 macroalgae and 14 invertebrates in July and October 2007 (Table 2). In contrast to the endobenthic community, we detected effects of $S$. muticum on epibenthic species occurrence. S. muticum density significantly affected epibenthic species number in July (two-factorial ANOVA, $F_{3 / 13}=11.02$, $\mathrm{MS}=10.24, p=0.001$ ) (Fig. 4). Mean associated species number of oyster plots without $S$. muticum $(23.4 \pm 1.1)$ was significantly higher than of plots with a $S$. muticum density of 15 ind. $\mathrm{m}^{-2}(20.6 \pm 1.3$; Tukey's test, $p=0.015$ ) and of 45 ind. $\mathrm{m}^{-2}$ (20.0 \pm 1.3 ; Tukey's test, $p=0.008$ ). Additionally, we detected a significant difference between the mean species number of the treatment with $7 \mathrm{~S}$. muticum ind. $\mathrm{m}^{-2}$ $(22.40 \pm 0.89)$ and the one with 45 ind. $\mathrm{m}^{-2}$ (Tukey's test, $\left.p=0.008\right)$. In October, however, no significant effect of $S$. muticum density on species number was detected (two-factorial ANOVA, $F_{3 / 13}=1.31$, MS $=4.46$, $p=0.313$ )

The mean total percentage coverage of all epibiont species oyster $^{-1}$ was also significantly affected by $S$. muticum density in

Table 2

List of sessile species detected in experimental treatments of different Sargassum muticum densities (ind. $\mathrm{m}^{-2}$ ) in July and October 2007.

\begin{tabular}{|c|c|c|c|c|c|c|c|c|}
\hline \multirow[t]{2}{*}{ Species } & \multicolumn{4}{|c|}{ July } & \multicolumn{4}{|c|}{ October } \\
\hline & 0 & 7 & 15 & 45 & 0 & 7 & 15 & 45 \\
\hline \multicolumn{9}{|l|}{ Algae } \\
\hline \multicolumn{9}{|l|}{ Chlorophyta } \\
\hline Bryopsis lyngbyei Hornem. & $\mathrm{p}$ & $\mathrm{p}$ & $\mathrm{p}$ & $\mathrm{p}$ & $\mathrm{p}$ & $\mathrm{p}$ & $\mathrm{p}$ & $\mathrm{p}$ \\
\hline Chaetomorpha aerea (Dillwyn) Kützing & & & $\mathrm{p}$ & & & & & \\
\hline Enteromorpha spp. Link & $\mathrm{p}$ & $\mathrm{p}$ & c & $\mathrm{p}$ & $\mathrm{p}$ & $\mathrm{p}$ & $\mathrm{p}$ & $\mathrm{p}$ \\
\hline Ulva spp. & $\mathrm{p}$ & $\mathrm{p}$ & $\mathrm{p}$ & $\mathrm{p}$ & & & & \\
\hline \multicolumn{9}{|l|}{ Phaeophyta } \\
\hline Ectocarpus spp. Lyngb. & $\mathrm{p}$ & $\mathrm{p}$ & $\mathrm{p}$ & $\mathrm{p}$ & $\mathrm{p}$ & $\mathrm{p}$ & $\mathrm{p}$ & $\mathrm{p}$ \\
\hline Elachista fucicola (Velley) Aresch. & $\mathrm{a}$ & $\mathrm{a}$ & c & $\mathrm{c}$ & & & & \\
\hline Petalonia fascia (O.F.Müll.) O. Kuntze & c & $\mathrm{c}$ & $\mathrm{a}$ & $\mathrm{a}$ & $\mathrm{p}$ & $\mathrm{p}$ & $\mathrm{p}$ & $\mathrm{p}$ \\
\hline Sargassum muticum (Yendo) Fensholt & & & & & $\mathrm{c}$ & $\mathrm{c}$ & $\mathrm{c}$ & $\mathrm{C}$ \\
\hline \multicolumn{9}{|l|}{ Rhodophyta } \\
\hline Acrochaetium spp. Nägeli & $\mathrm{p}$ & c & c & $\mathrm{p}$ & & & & \\
\hline Antithamnion plumula (Ellis) Thur. In Le Jolis & c & c & c & $\mathrm{p}$ & c & c & c & $\mathrm{p}$ \\
\hline Chondrus crispus Stackhouse & $\mathrm{p}$ & c & $\mathrm{p}$ & $\mathrm{p}$ & $\mathrm{p}$ & $\mathrm{p}$ & $\mathrm{p}$ & $\mathrm{p}$ \\
\hline Ceramium nodulosum (Lightf.) Ducluz. & $\mathrm{p}$ & $\mathrm{p}$ & c & $\mathrm{p}$ & $\mathrm{p}$ & $\mathrm{p}$ & $\mathrm{p}$ & $\mathrm{p}$ \\
\hline Dumontia incrassata (O.F. Müll) Lamour & $\mathrm{p}$ & & & & c & $\mathrm{p}$ & $\mathrm{p}$ & $\mathrm{p}$ \\
\hline Erythrotrichia spp. & $\mathrm{p}$ & & $\mathrm{p}$ & & & & & \\
\hline Polysiphonia nigrescens (Huds.) Grev. & $\mathrm{d}$ & $\mathrm{a}$ & $\mathrm{a}$ & $\mathrm{a}$ & $\mathrm{c}$ & $\mathrm{c}$ & c & $\mathrm{p}$ \\
\hline Polysiphonia violacea (Roth) Spreng. & $\mathrm{c}$ & $\mathrm{c}$ & c & $\mathrm{p}$ & $\mathrm{p}$ & $\mathrm{p}$ & $\mathrm{p}$ & $\mathrm{p}$ \\
\hline Polysiphonia elongata (Huds.) Spreng. & c & c & c & $\mathrm{p}$ & $\mathrm{p}$ & $\mathrm{p}$ & $\mathrm{p}$ & $\mathrm{p}$ \\
\hline Porphyra sp. & & $\mathrm{p}$ & $\mathrm{p}$ & & & & & \\
\hline \multicolumn{9}{|l|}{ Fauna } \\
\hline \multicolumn{9}{|l|}{ Porifera } \\
\hline Halichondria panicea (Pallas) & $\mathrm{p}$ & $\mathrm{p}$ & $\mathrm{p}$ & & $\mathrm{C}$ & $\mathrm{c}$ & c & $\mathrm{p}$ \\
\hline \multicolumn{9}{|l|}{ Cnidaria } \\
\hline Clytia hemispherica (L.) & $\mathrm{p}$ & & & & & & & \\
\hline Obelia longissima (Pallas) & $\mathrm{p}$ & $\mathrm{p}$ & $\mathrm{p}$ & $\mathrm{p}$ & $\mathrm{p}$ & $\mathrm{p}$ & $\mathrm{p}$ & $\mathrm{p}$ \\
\hline Obelia geniculata (L.) & $\mathrm{p}$ & & & & & & & \\
\hline Sagartiogeton undatus (Müller) & $\mathrm{a}$ & $\mathrm{a}$ & $\mathrm{a}$ & $\mathrm{a}$ & $\mathrm{p}$ & $\mathrm{p}$ & $\mathrm{p}$ & $\mathrm{p}$ \\
\hline Sarsia tubulosa (M.Sars) & $\mathrm{p}$ & & $\mathrm{p}$ & $\mathrm{p}$ & $\mathrm{p}$ & $\mathrm{p}$ & $\mathrm{p}$ & $\mathrm{p}$ \\
\hline \multicolumn{9}{|l|}{ Ciliophora } \\
\hline Vorticella sp. & $\mathrm{p}$ & $\mathrm{p}$ & $\mathrm{p}$ & $\mathrm{p}$ & $\mathrm{p}$ & $\mathrm{p}$ & $\mathrm{p}$ & $\mathrm{p}$ \\
\hline \multicolumn{9}{|l|}{ Mollusca } \\
\hline Crepidula fornicata (L.) & c & c & c & c & $\mathrm{p}$ & c & c & $\mathrm{c}$ \\
\hline Lepidochitonia cinerea (L.) & $\mathrm{p}$ & c & $\mathrm{p}$ & $\mathrm{p}$ & $\mathrm{p}$ & $\mathrm{p}$ & $\mathrm{p}$ & $\mathrm{p}$ \\
\hline \multicolumn{9}{|l|}{ Crustacea } \\
\hline Elminius modestus Darwin & $\mathrm{a}$ & $\mathrm{a}$ & $\mathrm{c}$ & $\mathrm{c}$ & $\mathrm{d}$ & $\mathrm{d}$ & a & $\mathrm{a}$ \\
\hline Balanus crenatus Bruguière & d & d & d & d & a & $\mathrm{a}$ & a & c \\
\hline Semibalanus balanoides (L.) & $\mathrm{p}$ & $\mathrm{p}$ & $\mathrm{p}$ & $\mathrm{p}$ & $\mathrm{p}$ & $\mathrm{p}$ & $\mathrm{p}$ & $\mathrm{p}$ \\
\hline Balanus improvisus Darwin & $\mathrm{p}$ & $\mathrm{p}$ & $\mathrm{p}$ & $\mathrm{p}$ & $\mathrm{p}$ & $\mathrm{p}$ & $\mathrm{p}$ & $\mathrm{p}$ \\
\hline \multicolumn{9}{|l|}{ Tunicata } \\
\hline Molgula manhattensis (de Kay) & $\mathrm{p}$ & $\mathrm{p}$ & $\mathrm{p}$ & $\mathrm{p}$ & $\mathrm{p}$ & $\mathrm{p}$ & $\mathrm{p}$ & $\mathrm{p}$ \\
\hline Styela clava Herdman & & $\mathrm{p}$ & & & $\mathrm{p}$ & $\mathrm{p}$ & $\mathrm{p}$ & $\mathrm{p}$ \\
\hline Total number of epibenthic species 33 & 29 & 26 & 28 & 24 & 25 & 24 & 25 & 25 \\
\hline
\end{tabular}

Semi-quantitative data on mean species occurrence are given as: $p$ ) present: $<1 \%$ cover oyster ${ }^{-1}$; c) common: $1-5 \%$; a) abundant: $6-9 \%$ and d) dominant $\geq 10 \%$. 

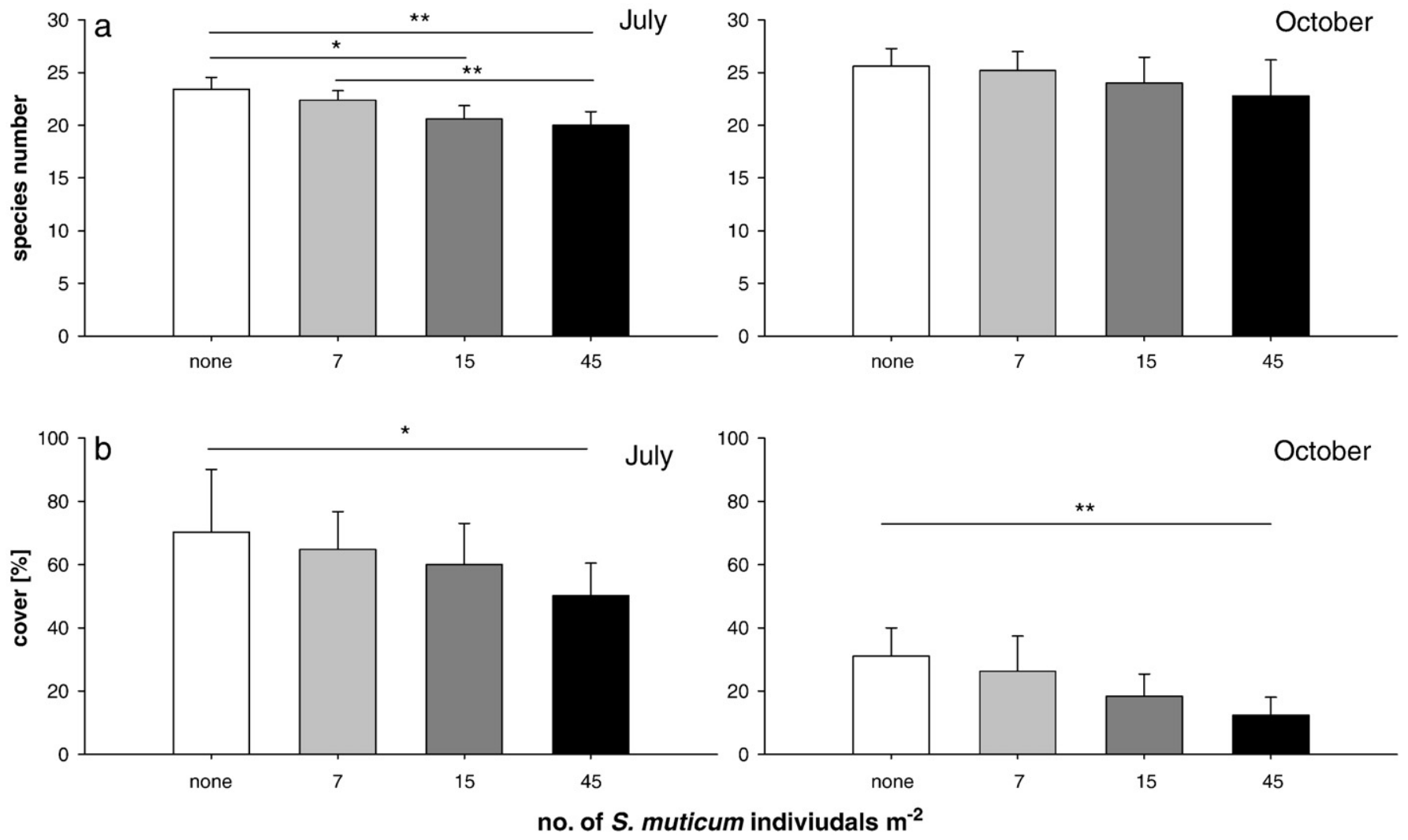

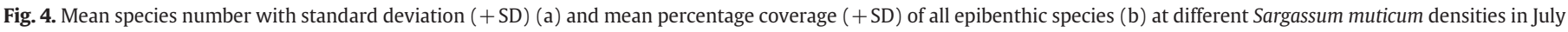
and October. Significant differences are denoted as asterisks $\left(p<0.05^{*}, p<0.01^{* *}\right)$.

both July (two-factorial ANOVA, $F_{3 / 13}=8.47$, MS $=217.21, p=0.002$ ) and October $\left(F_{3 / 13}=4.43, \mathrm{MS}=265.21, p=0.024\right)$ (Fig. 4). The overall coverage was significantly reduced in plots with a $S$. muticum density of 45 ind. $\mathrm{m}^{-2}$ compared to the treatment without S. muticum (Tukey's test for July, $p=0.011$; and for October, $p=0.001$ ). In July, total mean coverage of epibenthic organisms oyster ${ }^{-1}$ decreased with increasing algal density from $70.2 \%$ in the treatment without S. muticum to $50.1 \%$ in plots with a $S$. muticum density of 45 ind. $\mathrm{m}^{-2}$ (Fig. 4). A similar pattern was found in October with a decreasing total mean coverage oyster $^{-1}$ from $31.1 \%$ (without S. muticum) to $12.3 \%$ (S. muticum density of 45 ind. $\mathrm{m}^{-2}$ ).

\subsection{Species responses}

Considering species level we found a significant effect of S. muticum density on the percent coverage oyster ${ }^{-1}$ of the three most abundant understorey algal species (Fig. 5). The mean coverage oyster $^{-1}$ of Polysiphonia nigrescens (Hudson) Greville ex. Harvey was affected by $S$. muticum and significantly lower within the treatments with S. muticum than without in both July (two-factorial ANOVA, $F_{3 / 13}=10.72$, MS $=0.08, p=0.001$ ) and October (twofactorial ANOVA, $\left.F_{3 / 13}=3.90, \mathrm{MS}=0.030, p=0.034\right)$. P. nigrescens showed the highest percent coverage of all algal species identified.

In July, the coverage of Antithamnion plumula (J.Ellis) Thuret was also impaired by S. muticum and appeared to decrease with increasing S. muticum density (two-factorial ANOVA, $F_{3 / 13}=4.05, \mathrm{MS}=0.11$, $p=0.031$ ). Percentage coverage oyster ${ }^{-1}$ was significantly different between the treatment without $S$. muticum and the treatment with a S. muticum density of 45 ind. $\mathrm{m}^{-2}$ (Tukey's test, $p=0.045$ ). No significant differences could be observed in October.

Further, percentage coverage oyster ${ }^{-1}$ of the brown alga Elachista fucicola (Velley) Aresch. was reduced within the treatments with
S. muticum and showed a decreasing trend with increasing S. muticum densities in July (two-factorial ANOVA, $F_{3 / 13}=6.76$, MS $=0.14$, $p=0.005$ ). We detected a significant difference in $E$. fucicola coverage between the treatment without and with 45 individuals $\mathrm{m}^{-2}$ of S. muticum (Tukey's test $p=0.013$ ) (Fig. 5). Additionally, we recognized a significant coverage difference of $E$. fucicola between the treatment with seven S. muticum $\mathrm{m}^{-2}$ and 45 individuals $\mathrm{m}^{-2}$ (Tukey's test $p=0.031$ ).

Decreasing native algal coverage over the treatments with increasing S. muticum density per plot was also observed in the species Chondrus crispus Stackh. and Dumonita contorta (Gmel.) Ruprecht. However, coverage in comparison to the above mentioned macroalgae was low. Mean coverage was $<1.5 \%$ oyster $^{-1}$ in the treatment with no S. muticum (treatment in which they achieved highest coverage) and, thus, we decided not to test statistically.

Considering sessile faunal organisms, the most abundant species were the barnacles Balanus crenatus Bruguière and Elminius modestus Darwin. Decreasing numbers in abundance oyster ${ }^{-1}$ for both species were observed between the treatments of increasing $S$. muticum density in July as well as in October (Table 3). However, results were not significant. Recruitment of all other sessile invertebrate species was also not significantly affected by $S$. muticum.

\subsection{Water flow and sedimentation measurements}

The relative water flow velocity was indirectly quantified by measuring weight loss of gypsum muffins. The density of $S$. muticum significantly affected water flow velocity (two-factorial ANOVA, $F_{3 / 13}=$ $5.71, \mathrm{MS}=21.75, p=0.010$ ). Within the treatment without $S$. muticum water flow velocity was highest and significantly different from the treatment with $45 \mathrm{~S}$. muticum individuals $\mathrm{m}^{-2}$ which showed the lowest water flow velocity (Tukey's test, $p=0.004$ ) (Fig. 6). 

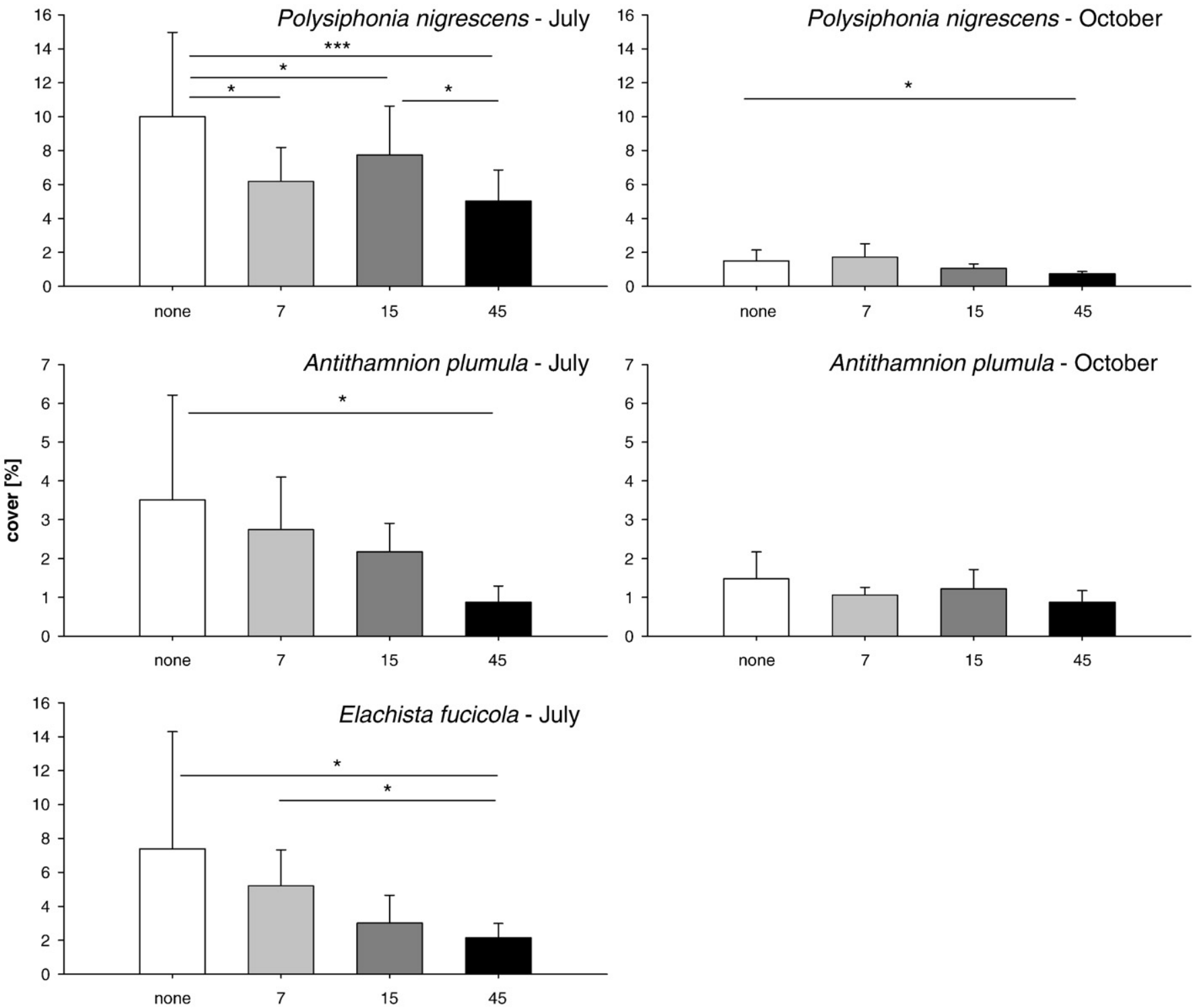

no. of S. muticum indiviudals $\mathrm{m}^{-2}$

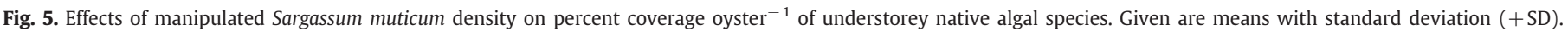
Significant results of the post-hoc Tukey test are denoted as asterisks $\left(p<0.05^{*}, p<0.01^{* *}, p<0.001^{* * *}\right)$.

We could not find any differences in sedimentation rate between the treatments of different S. muticum densities (Fig. 6). Neither the mean overall accumulated material per sediment trap (two-factorial ANOVA, $F_{3 / 13}=0.76, \mathrm{MS}=271.82, p=0.54$ ) nor a single sediment fraction of a certain grain size showed significant differences.

\section{Discussion}

Using a small-scale field experiment we investigated the effects of the invasive brown alga $S$. muticum on benthic organisms associated with experimental oyster plots in the sedimentary environment of the Wadden Sea. There were no significant effects of the S. muticum canopy on community level. Additionally, no significant effects were observed on the infauna. However, we detected significant effects of S. muticum abundance on native understorey algae.

\subsection{Effects of S. muticum on endobenthic organisms}

A S. muticum canopy could have an impact on endobenthic organisms mediated by the change of physical factors. More specifically: the

Table 3

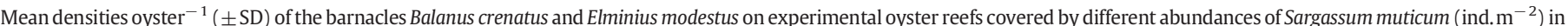
July and October 2007

\begin{tabular}{|c|c|c|c|c|c|c|c|c|}
\hline & \multicolumn{4}{|l|}{ July } & \multicolumn{4}{|l|}{ October } \\
\hline & 0 & 7 & 15 & 45 & 0 & 7 & 15 & 45 \\
\hline Balanus crenatus & $82.5 \pm 45.3$ & $65.5 \pm 20.2$ & $68.5 \pm 28.9$ & $65.8 \pm 19.8$ & $25.1 \pm 12.4$ & $20.7 \pm 5.2$ & $18.0 \pm 9.2$ & $11.9 \pm 3.1$ \\
\hline Elminius modestus & $28.7 \pm 7.8$ & $33.6 \pm 13.3$ & $21.0 \pm 8.1$ & $17.9 \pm 7.1$ & $61.1 \pm 12.4$ & $49.9 \pm 31.3$ & $32.5 \pm 14.1$ & $28.9 \pm 19.4$ \\
\hline
\end{tabular}




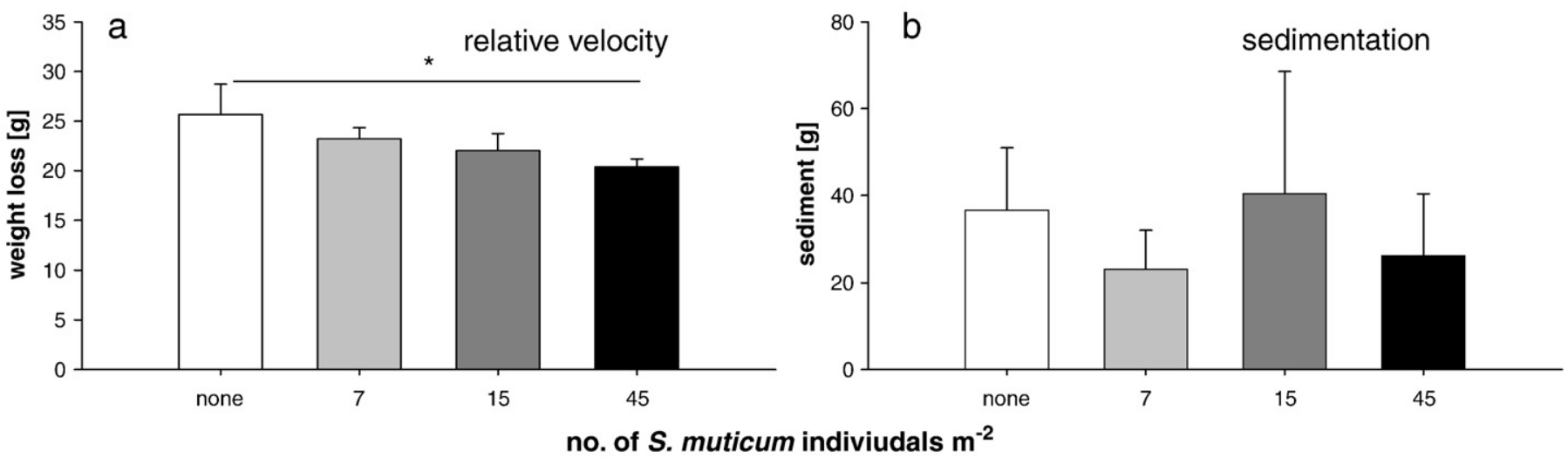

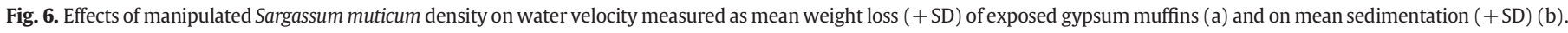
Significant results of the post-hoc Tukey test are denoted as asterisks $\left(p<0.05^{*}\right)$.

canopy can reduce water velocity and, thus, indirectly may enhance sedimentation. However, contradictory effects of macro-algal coverage on sedimentation are reported. Irving and Connell (2006) found reduced sedimentation beneath a canopy of Fucales. Eckman et al. (1989), by contrast, found greater rates of particle deposition beneath understorey kelps. In case of $S$. muticum, however, neither BrittonSimmons (2004), Strong et al. (2006) nor this study could detect any effect on sedimentation. An explanation that reduction of water velocity did not have any effect on sedimentation rate in our experiment could be the restricted plot area $\left(1 \mathrm{~m}^{2}\right)$. Particles that are slowed down above the plot would need some time to descend in the water column during which they are still transported by the current and they may touch the ground somewhere outside the plot. However, we did not observe any changes in sedimentation and sediment composition in the surrounding area of the experimental plots.

In contrast to the impacts of $S$. muticum on rocky shore communities, investigations on the effects on soft-bottom communities are scarce. Strong et al. (2006) detected significant differences between the endobenthic assemblages underneath $S$. muticum canopy and those in adjacent uncovered areas. They attribute the observed changes in endobenthic assemblage to shading, flow suppression and temperature stratification. Our results, by contrast, revealed no effects of S. muticum canopy on infauna. In accordance to the results of Strong et al. (2006) this pattern can be explained by the experimental time period which was restricted to four months. However, Albrecht and Reise (1994) also show that the infauna associated with mussel beds of $M$. edulis in the Wadden Sea was not affected by a heavy coverage with the bladder wrack Fucus vesiculosus forma mytili (Nienburg) despite of an increased sedimentation rate. It is likely that the endobenthic organisms are more affected by the bivalves lying directly at the sediment surface than by the algal coverage above the bivalve beds. Görlitz (2005) and Kochmann et al. (2008), for example, show that aggregations of blue mussels $M$. edulis beds and oysters $C$. gigas have different effects on the endobenthic community indicating that endobenthic organisms are strongly influenced by the kind of bivalve species at the sediment surface.

\subsection{Effects of S. muticum on sessile epibenthic organisms}

Although we detected a significantly reduced species number of epibionts on oyster beds as an effect of $S$. muticum coverage in July 2007 (but not in October) our results indicate that the differences in composition of an epibenthic soft-bottom oyster bed community in the Wadden Sea are small. However, we recognized a decrease of the mean overall coverage of sessile species on oyster beds with S. muticum in both July and October 2007 which is caused by a reduction of native macroalgae. No significant effect on the abundance of sessile benthic invertebrates could be detected.
The effect of S. muticum canopy on the coverage of native macroalgae was significant for three abundant species: P. nigrescens, A. plumula (both Rhodophyta) and E. fucicola (Phaeophyta). The overall trend was similar: the percentage cover decreased with increasing $S$. muticum density. Negative effects of $S$. muticum canopy on abundance of native understorey algae in subtidal habitats was also found by Curiel et al. (1998) in the Mediterranean, by Staehr et al. (2000) in the North Sea and by Britton-Simmons (2004) in the eastern Pacific.

The red macroalga $P$. nigrescens was the most dominant understorey algal species on the experimental oyster plots and was strongly affected by increased S. muticum densities in both July and October. Similarly, Curiel et al. (1998) and De Wreede (1983) report negative effects of a S. muticum canopy on otherwise dominant species of the order Ceramiales, Rhodophyta. Interestingly, Buschbaum et al. (2006) found that $P$. nigrescens grows as an epiphyte on S. muticum that may outweigh the reduction of P. nigrescens attached to $C$. gigas. However, in contrast to the oysters, $S$. muticum only represents an ephemeral habitat because the thalli break off in autumn and float away together with its associated species community.

The high occurrence of E. fucicola attached to oyster shells was not expected because this species is generally described as an epiphytic macroalga mainly growing on Fucus-species. However, Kornmann and Sahling (1977) found that E. fucicola may also be very abundant on other substrates in the Wadden Sea. In October, E. fucicola was not found because its main growing season is limited from April to August in the area (Kornmann and Sahling, 1977).

Reasons for algal coverage reduction below the S. muticum canopy could be changes in physical factors. The detected reduction in water flow is unlikely to result in a difference of nutrient availability between treatments because of the restricted plot size of $1 \mathrm{~m}^{2}$ in our experiment. Additionally, Britton-Simmons (2004) found no effect of S. muticum on nutrient availability for understory algae. Critchley et al. (1990a) recognized a temperature stratification caused by the S. muticum canopy. However, incidental water temperature measurements revealed no differences inside and outside S. muticum aggregations in our experimental plots. One important factor causing effects on other algae may be the reduction of light by S. muticum coverage and the importance of the shading effect of $S$. muticum canopy was assumed by several authors (Curiel et al., 1998; Critchley et al., 1990a; Britton-Simmons, 2004; Strong et al., 2006; Domisch, 2008). Similar to their results casual light measurements in our experiment showed that beneath $S$. muticum canopy light was less than $5 \%$ of the uncovered plot at the same water depth. Since S. muticum is a pseudoperennial species with only the holdfast persisting through the year the shading effect is restricted to spring and summer (Norton, 1977). However, this is also the main growing season for most native macroalgae occurring in the area. 
As shown for native macroalgae, S. muticum may also affect sessile benthic invertebrates recruiting and living below its canopy by mechanical disturbance of sweeping algal fronds (Jenkins et al., 1999; Leonard, 1999; Connell, 2003) and reduction in light and water flow. A light reduction favours the settlement of many invertebrate larvae that become photonegative at the end of their larval phase (Duggins et al., 1990; Connell, 2003). Additionally, by the suppression of water flow a depositional environment may emerge under the canopy where larval settlement is facilitated (Eckman et al., 1989; Leonard, 1999). Another important effect which acts more indirectly is the enhanced consumer pressure caused by the hiding opportunities beneath a canopy (Bertness et al., 1999). However, we obtained no data about predator abundance on the different plots. All these mentioned possible effects caused by $S$. muticum seem to be of less importance on oyster beds in the sedimentary environment of the Wadden Sea because S. muticum canopy did not affect the abundance of benthic sessile invertebrates. Similar results were obtained by Britton-Simmons (2004) who found no influence of a subtidal S. muticum canopy on benthic invertebrates at the Pacific coast of North America.

\subsection{Conclusions}

The introduction of S. muticum to the Wadden Sea and its occurrence on soft-bottom oyster beds may cause different effects. Epibenthic and endobenthic community composition at oyster aggregations seem to be not affected while single native algal species show a decrease in abundance. Additionally, S. muticum provides habitat for a rich epibiont species community associated with the algal thalli (Buschbaum et al., 2006). The ongoing dispersal of $C$. gigas and its spread into the shallow subtidal zone of the Wadden Sea result in a marked augmentation of biogenic hard substrate in an environment otherwise dominated by unstable sediments. This expansion may partly counterbalance the loss of highly diverse algae and invertebrate communities associated with subtidal native oyster (Ostrea edulis L.) and blue mussel beds (M. edulis L.) which were strongly overfished and disappeared from the Wadden Sea area in the second half of the 20th century (Hagmeier and Kändler, 1927; Saier et al., 2002; Cadée, 2007). Especially native macroalgae could strongly profit from the new oyster reefs because they provide an additional substratum for attachment. However, these structures are also used by the hitchhiking invader S. muticum. Dense canopies of S. muticum may reduce the establishment and occurrence of native macroalgae and may, therefore, limit the facilitative effect of Pacific oyster beds on native algae in the shallow subtidal zone. The invasion process of $S$. muticum is still ongoing and in summer 2009 we observed densities up to $50 \mathrm{~S}$. muticum individuals $\mathrm{m}^{-2}$ attached to oyster beds in the shallow subtidal zone (Buschbaum and Reise, unpublished data) indicating that densities used in our experiments represent the current natural situation. However, due to the dynamic process of $S$. muticum invasion in the Wadden Sea we assume a further increase of its densities which could amplify the ecological effects on native species found in our study.

\section{Acknowledgements}

We are grateful to Werner Armonies, Anthony Chapman, Tobias Dolch, Karsten Reise, Nina Eschweiler and Sophia Witte for reading former drafts of this manuscript. We thank Markus Molis and Sami Domisch for long discussion on different experimental designs and possible effects of $S$. muticum in native environments. The comments and suggestions of two anonymous reviewers improved the manuscript considerably. The Heinrich Böll Foundation supported the studies of A.C. Lang financially and ideally.

\section{References}

Albrecht, A., Reise, K., 1994. Effects of Fucus vesiculosus covering intertidal mussel beds in the Wadden Sea. Helgol. Meeresunters. 48, 243-256.
Ambrose, R.F., Nelson, B.V., 1982. Inhibition of giant kelp recruitment by an introduced brown alga. Bot. Mar. 25, 265-267.

Austen, G., 1994a. Hydrodynamics and particulate matter budget of Königshafen, southeastern North Sea. Helgol. Mar. Res. 48, 183-200.

Austen, I., 1994b. The surficial sediments of Königshafen - variations over the past 50 years. Helgol. Mar. Res. 48, 163-171.

Bayerl, K.-A., Higelke, B., 1994. The development of northern Sylt during the Latest Holocene. Helgol. Mar. Res. 48, 145-162.

Bertness, M.D., Leonard, G.H., Levine, J.M., Schmidt, P.R., Ingraham, A.O., 1999. Testing the relative contribution of positive and negative interactions in rocky intertidal communities. Ecology 80 (8), 2711-2726.

Borthagaray, A.I., Carranza, A., 2007. Mussels as ecosystem engineers: their contribution to species richness in a rocky littoral community. Acta Oecologica 31, 243-250.

Britton-Simmons, K.H., 2004. Direct and indirect effects of the introduced alga Sargassum muticum on benthic, subtidal communities of Washington State, USA. Mar. Ecol. Prog. Ser. 277, 61-78.

Bruno, J.F., 2000. Facilitation of cobble beach plant communities through habitat modification by Spartina alterniflora. Ecology 81 (5), 1179-1192.

Buschbaum, C., Chapman, A.S., Saier, B., 2006. How an introduced seaweed can affect epibiota diversity in different coastal systems. Mar. Biol. 148, 743-754.

Buschbaum, C., Dittmann, S., Hong, J.-S., Hwang, I.-S., Strasser, M., Thiel, M., Valdivia, N., Yoon, S.-P., Reise, K., 2009. Mytilid mussels: global habitat engineers in coastal sediments. Helgol. Mar. Res. 63, 47-48.

Cadée, G.C., 2007. Vervangen de recente Japanse oesterriffen de vroegere oesterbanken? Levende Nat. 108 (2), 62-65.

Callaway, J.C., Josselyn, M.N., 1992. The introduction and spread of smooth cordgrass (Spartina alterniflora) in South San Francisco Bay. Estuaries 15 (No 2), 218-226.

Clarke, K.R., Warwick, R.H., 2001. Change in Marine Communities: An Approach to Statistical Analyses and Interpretation, 2nd ed. PRIMER-E Ltd, Plymouth, UK.

Connell, S.D., 2003. Negative effects overpower the positive of kelp to exclude invertebrates from the understory community. Oecologia 137, 97-103.

Connell, S.D., 2005. Assembly and maintenance of subtidal habitat heterogeneity: synergistic effects of light penetration and sedimentation. Mar. Ecol. Prog. Ser. 289, 53-61.

Critchley, A.T., Dijkema, R., 1984. On the presence of the introduced brown alga Sargassum muticum, attached to commercially imported Ostrea edulis in the S.W. Netherlands. Bot. Mar. 27, 211-216.

Critchley, A.T., De Visscher, P.R.M., Nienhuis, P.H., 1990a. Canopy characteristics of the brown alga Sargassum muticum (Fucales, Phaeophyta) in Lake Grevelingen, southwest Netherlands. Hydrobiologia 204 (205), 211-217.

Critchley, A.T., Farnham, W.F., Yoshida, T., Norton, T.A., 1990b. A bibliography of the invasive alga Sargassum muticum (Yendo) Fensholt (Fucales; Sargassaceae). Bot. Mar. 33, 551-562.

Crooks, J.A., Khim, H.S., 2002. Characterizing ecosystem-level consequences of biological invasions: the role of ecosystem engineers. OIKOS 97, 153-166.

Cuddington, K., Hastings, A., 2004. Invasive engineers. Ecol. Model. 178, 335-347.

Curiel, D., Bellemo, G., Marzocchi, M., Scattolin, M., Parisi, G., 1998. Distribution of introduced Japanese macroalgae Undaria pinnatifida, Sargassum muticum (Phaeophyta) and Antithamnion pectinatum (Rhodophyta) in the Lagoon of Venice. Hydrobiologia $385,17-22$.

De Wreede, R.E., 1983. Sargassum muticum (Fucales, Phaeophyta): regrowth and interaction with Rhodomela larix (Ceramiales, Rhodophyta). Phycologia 22 (2), 153-160.

Diederich, S., Nehls, G., van Beusekom, J.E.E., Reise, K., 2005. Introduced pacific oysters (Crassostrea gigas) in the northern Wadden Sea: invasion accelerated by warm summers? Helgol. Mar. Res. 59, 97-106.

Domisch, S., 2008. Effekte des eingewanderten Japanischen Beerentangs Sargassum muticum Yendo (Fensholt) auf die Diversität und Struktur makrobenthischer Gemeinschaften im Helgoländer Felswatt. Dipl. Thesis, University of Oldenburg.

Druehl, L., 1973. Marine transplantations. Science 170, 12.

Duggins, D.O., Eckman, J.E., Sewell, A.T., 1990. Ecology of understory kelp environments. II. Effects of kelps on recruitment of benthic invertebrates. J. Exp. Mar. Biol. Ecol. 143, $27-45$.

Eckman, J.E., Duggins, D.O., Sewell, A.T., 1989. Ecology of understory kelp environments. I Effects of kelps on flows and particle transport near the bottom. J. Exp. Mar. Biol. Ecol. 129, 173-187.

Fletcher, R.L., 1975. Studies on the recently introduced brown alga Sargassum muticum (Yendo) Fensholt II. Regenerative ability. Bot. Mar. 18, 157-162.

Fletcher, R.L., 1980. Studies on the recently introduced brown alga Sargassum muticum (Yendo) Fensholt. III. Periodicity in gamete release and 'incubation' of early germling stages. Bot. Mar. 23, 425-432.

Gardner, W.D., 1980. Field assessment of sediment traps. J. Mar. Res. 38, 41-52.

Görlitz, S., 2005. Neue Riffe im Wattenmeer: Die Pazifische Auster Crassostrea gigas und ihre assoziierte Lebensgemeinschaft. Dipl. Thesis, University of Kiel.

Grosholz, E.D., Ruiz, G.M., Dean, C.A., Shirley, K.A., Maron, J.L., Connors, P.G., 2000. The impacts of a nonindigenous marine predator in a California bay. Ecology 81 (5), 1206-1224.

Gutiérrez, J.L., Jones, C.G., Strayer, D.L., Iribarne, O.O., 2003. Mollusks as ecosystem engineers: the role of shell production in aquatic habitats. Oikos 101, 79-90.

Hagmeier, A., Kändler, R., 1927. Neue Untersuchungen im nordfriesischen Wattenmeer und auf den fiskalischen Austernbänken. Wiss. Meeresunters. (Abt. Helgoland) 16, 1-90.

Hales, J.M., Fletcher, R.L., 1989. Studies on the recently introduced brown alga Sargassum muticum (Yendo) Fensholt IV. The effect of temperature, irradiance and salinity on germling growth. Bot. Mar. 32, 167-176.

Harries, D.B., Harrow, S., Wilson, J.R., Mair, J.M., Donnan, D.W., 2007. The establishment of the invasive alga Sargassum muticum on the west coast of Scotland: a preliminary assessment of community effects. J. Mar. Biol. Assoc. U.K. 87, 1057-1067. 
Irving, A.D., Connell, S.D., 2006. Predicting understorey structure from the presence and composition of canopies: an assembly rule for marine algae. Oecologia 148, 491-502.

Jenkins, S.R., Norton, T.A., Hawkins, S.J., 1999. Settlement and post-settlement interactions between Semibalanus balanoides (L.) (Crustacea: Cirripedia) and three species of fucoid algae. J. Exp. Mar. Biol. Ecol. 236, 49-67.

Jones, C.G., Lawton, J.H., Shachak, M., 1994. Organisms as ecosystem engineers. OIKOS 69, 373-386.

Kennelly, S.J., 1989. Effects of kelp canopies on understorey species due to shade and scour. Mar. Ecol. Prog. Ser. 50, 215-224.

Kochmann, J., Buschbaum, C., Volkenborn, N., Reise, K., 2008. Shift from native mussels to alien oysters: differential effects of ecosystem engineers. J. Exp. Mar. Biol. Ecol. 364, 1-10.

Kornmann, P., Sahling, P.H., 1977. Meeresalgen von Helgoland. Helgol. Wiss. Meeresunters. 29, 1-289.

Leonard, G.H., 1999. Positive and negative effects of intertidal algal canopies on recruitment and survival of barnacles. Mar. Ecol. Prog. Ser. 178, 241-249.

Norton, T.A., 1977. The growth and development of Sargassum muticum (Yendo) Fensholt. J. Exp. Mar. Biol. Ecol. 26, 41-53.

Norton, T.A., 1981. Gamete expulsion and release in Sargassum muticum. Bot. Mar. 24, $465-470$.

Olabarria, C., Rodil, I.F., Incera, M., Troncoso, J.S., 2009. Limited impact of Sargassum muticum on native algal assemblages from rocky intertidal shores. Mar. Environ. Res.67, 153-158.

Polte, P., Buschbaum, C., 2008. Native pipefish Entelurus aequoreus are promoted by the introduced seaweed Sargassum muticum in the northern Wadden Sea, North Sea. Aquat. Biol. 3, 11-18.

Reise, K., 1985. Tidal Flat Ecology. Springer, Berlin Heidelberg New York. 191 pp.

Reise, K., 2008. Oysters: natives gone and aliens coming. In: Rabitsch, W., Essl, W.F., Klingenstein, F. (Eds.), Biological Invasions-From Ecology to Conservation: Neobiota, vol. 7, pp. 259-263.

Reise, K., Herre, E., Sturm, M., 1989. Historical changes in the benthos of the Wadden Sea around the island of Sylt in the North Sea. Helgol. Meeresunters. 43, 417-433.

Reise, K., Herre, E., Sturm, M., 1994. Biomass and abundance of macrofauna in intertidal sediments of Königshafen in the northern Wadden Sea. Helgol. Meeresunters. 48, 201-215.

Reise, K., Gollasch, S., Wolff, W.J., 2002. Introduced marine species of the North Sea coasts. In: Leppäkoski, E. (Ed.), Invasive Aquatic Species of Europe, pp. 260-266.

Ruesink, J.L., Feist, B.E., Harvey, C.J., Hong, J.S., Trimble, A.C., Wisehart, L.M., 2006. Changes in productivity associated with four introduced species: ecosystem transformation of a 'pristine' estuary. Mar. Ecol. Prog. Ser. 311, 203-215.

Russell, B.D., 2007. Effects of canopy-mediated abrasion and water flow on the early colonisation of turf-forming algae. Mar. Freshw. Res. 58, 657-665.

Saier, B., Buschbaum, C., Reise, K., 2002. Subtidal mussel beds in the Wadden Sea: threatened oases of biodiversity. Wadden Sea Newsl. (1), 12-14.
Sánchez, I., Fernández, C., 2005. Impact of the invasive seaweed Sargassum muticum (Phaeophyta) on an intertidal macroalgal assemblage. J. Phycol. 41, 923-930.

Sánchez, I., Fernández, C., Arrontes, J., 2005. Long-term changes in the structure of intertidal assemblages after invasion by Sargassum muticum (Phaeophyta). J. Phycol.41, 942-949.

Schaffelke, B., Hewitt, C.L., 2007. Impacts of introduced seaweeds. Bot. Mar. 50, 397-417.

Schaffelke, B., Smith, J.E., Hewitt, C.L., 2006. Introduced macroalgae - a growing concern. J. Appl. Phycol. 18, 529-541.

Schories, D., Albrecht, A., 1996. Sargassum muticum-Der Japanische Beerentang im deutschen Wattenmeer. Nat. Mus. 125 (3), 92-98.

Schories, D., Albrecht, A., Lotze, H., 1997. Historical changes and inventory of macroalgae from Königshafen Bay in the northern Wadden Sea. Helgol. Mar. Res. 51, 321-341.

Simberloff, D., Von Holle, B., 1999. Positive interactions of nonindigenous species: invasional meltdown. Biol. Invas. 1, 21-32.

Sousa, R., Gutiérrez, J.L., Aldridge, D.C., 2009. Non-indigenous invasive bivalves as ecosystem engineers. Biol. Invasions 11, 2367-2385.

Staehr, P.A., Pedersen, M.F., Thomsen, M.S., Wernberg, T., Krause-Jensen, D., 2000 Invasion of Sargassum muticum in Limfjorden (Denmark) and its possible impact on the indigenous macroalgal community. Mar. Ecol. Prog. Ser. 207, 79-88.

Strong, J.A., Dring, M.J., Maggs, C.A., 2006. Colonisation and modification of soft substratum habitats by the invasive macroalga Sargassum muticum. Mar. Ecol. Prog. Ser. 321, 87-97.

Thomsen, M.S., 2006. Spatio-temporal distribution patterns of the invasive macroalga Sargassum muticum within a Danish Sargassum-bed. Helgol. Mar. Res. 60, 50-58.

Toohey, B., Kendrick, G.A., Wernberg, T., Phillips, J.C., Malkin, S., Prince, J., 2004. The effects of light and thallus scour from Ecklonia radiata canopy on an associated foliose algal assemblage: the importance of photoacclimation. Mar. Biol. 144, 1019-1027.

Underwood, A.J., 1997. Experiments in Ecology: Their Logical Design and Interpretation Using Analysis of Variance. Cambridge Univ. Press, Cambridge.

Velimirov, B., Griffiths, C.L., 1979. Wave-induced kelp movement and its importance for community structure. Bot. Mar. 22, 169-172.

Viejo, R.M., 1997. The effects of colonization by Sargassum muticum on tidepoo macroalgal assemblages. J. Mar. Biol. Assoc. U.K. 77, 325-340.

Viejo, R.M., Arrontes, J., Andrew, N.L., 1995. An experimental evaluation of the effect of wave action on the distribution of Sargassum muticum in northern Spain. Bot. Mar. 38, 437-441.

Wallentinus, I., Nyberg, C.D., 2007. Introduced marine organisms as habitat modifiers. Mar. Pollut. Bull. 55, 323-332.

Williams, S.L., Smith, J.E., 2007. A global review of the distribution, taxonomy and impacts of introduced seaweeds. Annu. Rev. Ecol. Evol. Syst. 38, 327-359.

Wolff, W.J., 2005. Non-indigenous marine and estuarine species in the Netherlands. Zool. Medelingen 79, 1-116. 